thyroxine. The second part of the discourse exhibited recent discoveries which show that the carbon compounds of multivalent iodine present a much more extensive field than had been realized, wherein this element is seen to be classed less with bromine and chlorine than with elements such as antimony, arsenic, phosphorus, and nitrogen, yet has specific characters of its own.

\section{Chemistry in the Ancient World}

THE fortieth Bedson Lecture was delivered on November 26, at King's College, Newcastle-uponTyne, by Prof. J. R. Partington, on "Chemistry in the Ancient World". The lecture dealt mainly with the period 4000-1000 B.c., and showed how the outstanding achievements in applied chemistry during this period were made in three principal regions, namely Egypt, Mesopotamia and Crete. The working of metals appears before 3500 B.c. in Egypt and Mesopotamia and somewhat later in Crete and Cyprus. The earliest metal known was probably gold, although copper was known very early in Egypt. The metals silver, lead and iron were also known in the earliest period but were scarce. Refining of gold appears about 525 B.c. An important copper industry was established in Egypt, the malachite ore being mined in Sinai. The use of iron and steel is found among the Hittites and related peoples at the time of the eighteenth dynasty in Egypt, and iron was freely used by the later Assyrians. Brass was known in Palestine about 1400-1000 B.c., and, since the brass industry was later established in Cyprus, some relation between the two regions by way of Râs Shamra seems to be indicated. The techniques of metal workers differed in different regions. The production of bronze was an important event, and the source of the early tin is still doubtful. Zinc occurs in small quantities only in the Roman period. The production of black-topped pottery in Egypt was described and also the preparation of glazes. In some cases the results have been imitated with difficulty and only recently. Glass itself was known in Egypt and Mesopotamia in 3000 B.C., the Egyptians being very skilled in its manufacture and colouring, although blown glass does not seem to have been made until the beginning of the Christian era. The dyes indigo and safflower were used in ancient Egypt, and in Mesopotamia there were the beginnings of the petroleum industry, with extensive use of bitumen for cement and asphalt.

\section{Meteorites of the Gran Chaco}

THE announcement in The Times of November 9 by a Buenos Ayres correspondent of the discovery of as large mass of meteoric iron in the Campo del Cielo region of the Gran Chaco in the northern Argentine is puzzling. He refers to a "legendary meteorite" long ago spoken of as the "Mesón de Fierro" (iron inn), and assumed to be the source of the iron tips of Indian spears seen by the Spanish conquerors. The discovery of a large mass of native iron in this region was made by Hernán Mexía de Miraval in 1576. This, or perhaps another large mass, was seen by Miguel Rubin de Celis in 1783, and was describerl by him in the Philosophical Transactions in 1788. The weight of this mass has been variously estimated at from $13 \frac{1}{2}$ to 45 tons. Another mass of about one ton, found in 1803, was transported to Buenos Ayres during the war of independence with the idea of manufacturing it into armaments; and a portion, weighing 1,400 lb., of this was presented to the British Museum in $\mathbf{1 8 2 6}$ by Sir Woodbine Parish, who described it in the Philosophical Transactions in 1834. This is still on view in the Natural History Museum at South Kensington. More recently, a mass of $4,210 \mathrm{kgm}$. (more than 4 tons) was found in 1923 , another of $732 \mathrm{kgm}$. in 1925, and several other smaller masses. These have been transported to the National Museum in Buenos Ayres. The new report may perhaps refer to the rediscovery of the larger mass seen by Rubín de Celis in 1783 ; or, not unlikely, still another large mass may have been found. It is suggested that the boundary between the provinces of Santiago del Estero and El Chaco is defined by the position of the "Mesón de Fierro". But as shown on a map of the region (Geog. J., 81, 238; 1933) masses of iron have been found on both sides of this boundary line. Evidently at this place there was an unusually large shower of meteoric irons. The history of the several masses has been given by Dr. Antenor Alvarez "El meteorito del Chaco" (Buenos Ayres, 1926, pp. 222). But the associated meteorite craters, a group of round and shallow depressions (hoyos or pozos), still require investigation.

\section{Iron Age Site in the Vale of White Horse, Berks}

Excavation of an archæological site at Frilford in the Vale of White Horse, Berks, has afforded interesting evidence of a succession of cultures during a period, which if not prolonged in archæological perspective, was at least of considerable duration, extending from the early Iron Age to Saxon times. The site lies close to the Oxford-Wantage road, where it crosses the River Ock, and is situated not more than a hundred yards from a well-known cemetery of the Roman and Saxon periods. The excavation, which was undertaken by the Oxford University Archæological Society at the suggestion of Sir Arthur Evans, was carried out during last term by undergraduate members of the Society with the co-operation of Mr. D. R. Harden of the Ashmolean Museum. The evidence of early Iron Age occupation, according to a report in The Times of December 6, is in the form of a series of pits, circular and irregular, dug in the limestone subsoil. These contain Iron Age $A 2$ pottery. In the largest found to date was a large hearth on a clay floor with, among other objects, a polished hammer-stone. In this period the district was remote and backward; but during the Roman occupation a small but well-built villa was erected on the site. This had a tiled roof and tessellated floor. Unfortunately, seekers after stone in later ages have left little of the walls but the foundation trenches, and the floors have suffered similarly. Samian pottery and coins point to an occupation from the first to the end of the fourth century. If this villa 